\title{
Mangroves of Southeastern Mexico: Palaeoecology and Conservation
}

\author{
Nuria Torrescano-Valle and Gerald A. Islebe* \\ El Colegio de la Frontera Sur, Unidad Chetumal, Herbario, AP 424, CP 77014 Chetumal, Quintana Roo, Mexico
}

\begin{abstract}
Pollen analysis on a sediment core from a mangrove area in southeastern Mexico was discussed and aspects of paleoecology, ecology and conservation were considered. The core spans the last 4000 years and evidences changes in a Rhizophora mangle dominated system. Between 3900 and 3500 cal yr BP, pollen data indicate higher levels of precipitation. Between 3600 and $3300 \mathrm{cal} \mathrm{yr} \mathrm{BP} \mathrm{tropical} \mathrm{forest} \mathrm{near} \mathrm{the} \mathrm{mangrove} \mathrm{area} \mathrm{is} \mathrm{established,} \mathrm{indicated} \mathrm{by} \mathrm{the}$ presence of Ficus, Moraceae, Fabaceae, Sapotaceae, Rubiaceae and Gymnopodium floribundum. Between 3300 and 3150 cal yr BP, development of tasistal vegetation is evidenced, based on taxa like Acoelorraphe wrightii and Thrinax radiata. The paleoecological evidence is discussed considering mangrove ecology and conservation. Mangroves in southeastern Mexico are impacted by natural hazards, like hurricanes and additionally human activities have severely damaged this economically important ecosystem.
\end{abstract}

Keywords: Paleoecology, mangroves, ecology, conservation, southeastern Mexico.

\section{INTRODUCTION}

Mangroves are tree and shrub- dominated ecosystems in the subtropics and tropics along coastlines and depends on saline and brackish environments. In southeastern Mexico, mangroves can be found along the coasts of the Yucatan Peninsula [1], and are distributed in depressions formed during the Pleistocene. Mangroves are more extensive when formed near the coral barriers [2]. Mangroves of the Caribbean area are often peat deposits due to the gradual accumulation of organic matter [3-5]. The mangrove forests of the Caribbean are fundamentally different from those receiving mineral sediment (e.g. in alluvial habitats) and thus represent a model system for the study of biotic contributions to elevation change (vertical accretion). The habitat stability of mangroves and other coastal wetlands ultimately depends on the capacity of the system to maintain soil elevations relative to sea level [6]. Mangroves provide a series of ecosystem services like coast line protection, carbon sequestration [7], formation of peat deposits among many others which are essential for sustainable fisheries [2].

Characteristic mangrove species in southeastern Mexico include Rhizophora mangle, Avicennia germinans, Laguncularia racemosa and Conocarpus erecta. Conocarpus erecta has been considered as an associated species [8], and is an important element in the mangrove forests of southeastern Mexico. Mangrove forests have been strongly affected during the last decades in Mexico, but especially in southeastern Mexico due to tourism, infrastructure development, aquaculture, agriculture, forestry and additionally natural hazards like hurricanes, large areas of mangrove forests have been damaged $[9,10]$. Available ecological studies on mangroves in southeastern Mexico are

*Address correspondence to this author at the El Colegio de la Frontera Sur, Unidad Chetumal, Herbario, AP 424, CP 77014 Chetumal, Quintana Roo, Mexico; Tel: +529838350440 , Ext. 4300; Fax: +529838350440 , Ext. 4300; E-mail: gislebe@ecosur.mx still rare and yet incomplete, and most of the studies had a floristic approach [11-13]. Strategies of recovery of mangrove forests after hurricane Wilma in 2005 area have been analyzed by Carrillo-Bastos et al., [14]. Earlier, De Jesús-Navarrete and Olivera-Rivera [15] estimated litter production of Rhizophora mangle in southern Quintana Roo.

Conservation efforts of mangrove areas are often in direct conflict with tourism development and although $L$. racemosa and $C$. erecta are considered threatened species and $R$. mangle as protected by NOM-059 (Mexican federal law protecting endangered species), in reality little is done to protect mangrove areas effectively. In CITES [16] neither $R$. mangle, L. racemosa nor C. erecta are mentioned.

Following Ellison and Stoddart [17], the vertical variation in ecstatic sea level has been reduced since 6000 $\mathrm{BP}$, for the Caribbean the sea level increase has been slowly since mid Holocene [18]. Based on Toscano and Mcintyre [4] and Gabriel et al., [19] 6600 sea-level rise flooded the Caribbean platform. Given to the relation between the rate of sediment accretion and rising of sea-level, many studies has been realised with the purpose of to establish the mangrove peat accretion on both historical an geological time scales [20]. The data about the climatic variations occurred during mid to late Holocene provide key information of natural change within a climatic system that is similar to the present, these data permit to create future projections of the sea-level rise [21].

Van Hengstum et al., [22] explain that two external factors exist which affect hydrogeology of the Yucatan peninsula, long-term sea-level oscillation vertically affect the water column to a regional and local scale, the regional precipitation affects aquifer recharge and level of groundwater. On a short-term the hurricanes can increase the sea-level at the coast and change of the level of the groundwater.

Palaeoecological studies of mangroves are still rare in the region. Islebe and Sánchez [23] gave evidence of 
Rhizophora mangle establishment in northern Quintana Roo around 3500 cal yr BP. From southern Quintana Roo, Torrescano and Islebe [24] show shifts from tropical forest vegetation to mangroves dominated vegetation during the middle Holocene, due to rising sea-level and changes of the Rio Hondo River. Gabriel et al., [19] present a core from cenote Aktun-ha (Central Quintana Roo) of ca 7000 yr BP highlighting mid Holocene sea level rise. Monacci et al., [25] and Woller et al., [26], analyzed cores from Belize, giving evidence of vegetation change during early and middle Holocene.

Rull [27] stresses the importance of palaeoecology to ecology, as a discipline based on ecological principles, but working on a different time scales. As mentioned by Delcourt and Delcourt [28] the paleoecological perspective is an extended view from ecology, as changes through large time intervals are considered and facilitate holistic understanding of historical, structural and functional development of modern ecosystems. Birks [29] and Haila [30] argue that nature conservation requires a historical perspective for two reasons, first, to defined clearly the concept of nature, and second, to established the minimum area for study and protection.

The aim of this paper is to document past changes in mangroves and to understand those changes with present day ecological knowledge of mangrove forests in southeastern Mexico in order to strengthen conservation efforts. Mangroves are good indicators of climate change, as they are subject to extreme impacts like sea level rise and hurricanes and additionally they are sensitive indicators to human induced changes.

\section{STUDY AREA}

The Mexican part of the Yucatan peninsula consists of three states, Campeche, Yucatán and Quintana Roo. Mangroves are typical along the coastline. Cores were taken in mangrove areas of Puerto Morelos, $30 \mathrm{~km}$ south of Cancun (Fig. 1). Mean annual temperature is ca $26^{\circ} \mathrm{C}$ and mean annual precipitation is about $1200 \mathrm{~mm}$ [23]. The mangrove area of Puerto Morelos is located west to the Botanical Garden, an area of natural vegetation dominated by medium statured tropical forest, others types like low tropical forest and mangroves are present in minor proportion. This classification is defined for height and composition [31]. Mangroves at Puerto Morelos have a maximum canopy height of $12 \mathrm{~m}$, which is rather low for mangrove stands. Snedaker and Pool [32], Lugo and Snedaker [33] and Pool et al., [34] discuss the possible influence of low hydrological exchange characteristic of karstic landscapes, the influence of calcium and nutrient poor environments of the Caribbean coast. However, hurricanes also must be considered as a possible cause for lower canopy heights, which can be considered as an adaptation to strong winds. The entangled structures of roots and reduced canopy have been identified in several studies [14]. Strong hurricanes have directly impacted the area during the last centuries and mangrove recovery is extremely slow [35]. The term mangroves includes four types of mangrove associations in southeasten Mexico: mixed mangrove with $R$. mangle, L. racemosa, Avicennia germinans and C. erecta, Conocarpus-Rhizophora association, pure $R$. mangle stands and mangrove species associated to Peten vegetation [11]. Pure mangrove stands are found on inundated and very saline soils [36]. Individual $R$. mangle trees have canopy heights between 8 and $10 \mathrm{~m}$. Dwarf mangroves (average height of $2 \mathrm{~m}$ ) of Rhizophora are mainly found in estuaries and coastal lagoons formed during the Upper Pleistocene, forming extensive wetlands with Cladium jamaicense [37-39]. Peten vegetation is defined as forest islands within mangrove areas, depending on water outflows in less saline conditions. C. erecta is well represented in those areas. Characteristic species are Ruppia maritima, Cladium jamaicense, Batis maritima and Acrostichium danaefolium. Conocarpus erecta and Rhizophora mangle are the dominant species in many mangrove areas along the Caribbean coast. $R$. mangle is enlisted as endangered species following NOM (Mexican list of endangered species). Mangrove stands are surrounded by medium statured tropical forest, sabana (local name) and tasistal vegetation, defined by dominance of must Acoelorraphe wrightii [39]. At present, mangrove forests in Puerto Morelos are strongly affected by hydrological variations due to road constructions, which interrupted the natural flow from mangroves to the Caribbean Sea.

\section{Methods}

A $110 \mathrm{~cm}$ core (MPM-2) was taken with a Dachnovsky corer in 2005 in the mangrove area of Puerto Morelos, ca $500 \mathrm{~m}$ from the coast line (Fig. 1). The core was taken in parts of $25 \mathrm{~cm}$ and taken to the Palynology laboratory of El Colegio de la Frontera Sur in Chetumal. In the lab subsamples of $1-2 \mathrm{~cm}$ were taken. Pollen was retrieved by standard acetolysis techniques [40]. Pollen slides were analyzed until a pollen sum of 300 grains was achieved. Core MPM-1 is used to compare the results. Based on floristic studies in the mangrove area and the surrounding botanical garden [23], identified taxa of fossil pollen were divided into four main groups: mangroves, medium statured tropical forest, disturbance vegetation and aquatics. A list of all pollen taxa and their ecological groups is given in Table 1. Pollen diagrams were made with Tilia 1.7.16 [41]. Two pollen zones were determined with CONISS (Cluster analysis) from Tilia (Fig. 2). Three AMS radiocarbon dates were used to establish a chronology, and all dates were calibrated with CALIB (version 6.0), this version use INTCAL09 datasets (Fig. 2) [42].

To analyze the response between taxa and predictable variables (depth, age) linear regression was used (Table 2). Prior to regression, tests of normality and homogeneity were applied $[43,44]$. InfoStat uses the method of least squares to obtain estimates $[45,46]$. The magnitude and direction of relationship between the variables with the highest value of linear regression (Table 2) are shown in Table 3. Fig. (4) shows Spearman correlation in order to determine the degree of association of each pair of variables [43-46].

\section{RESULTS}

Core MPM-1 with a depth of $190 \mathrm{~cm}$, shows humid conditions for the period 2500-1500 14C yr BP, Rhizophora mangle dominated with a good representation of taxa from the medium tropical forest. Between 1500-1200 14C yr BP, Conocarpus erecta dominated, $R$. mangle disappeared and other taxa appeared, suggesting drier climatic conditions and 


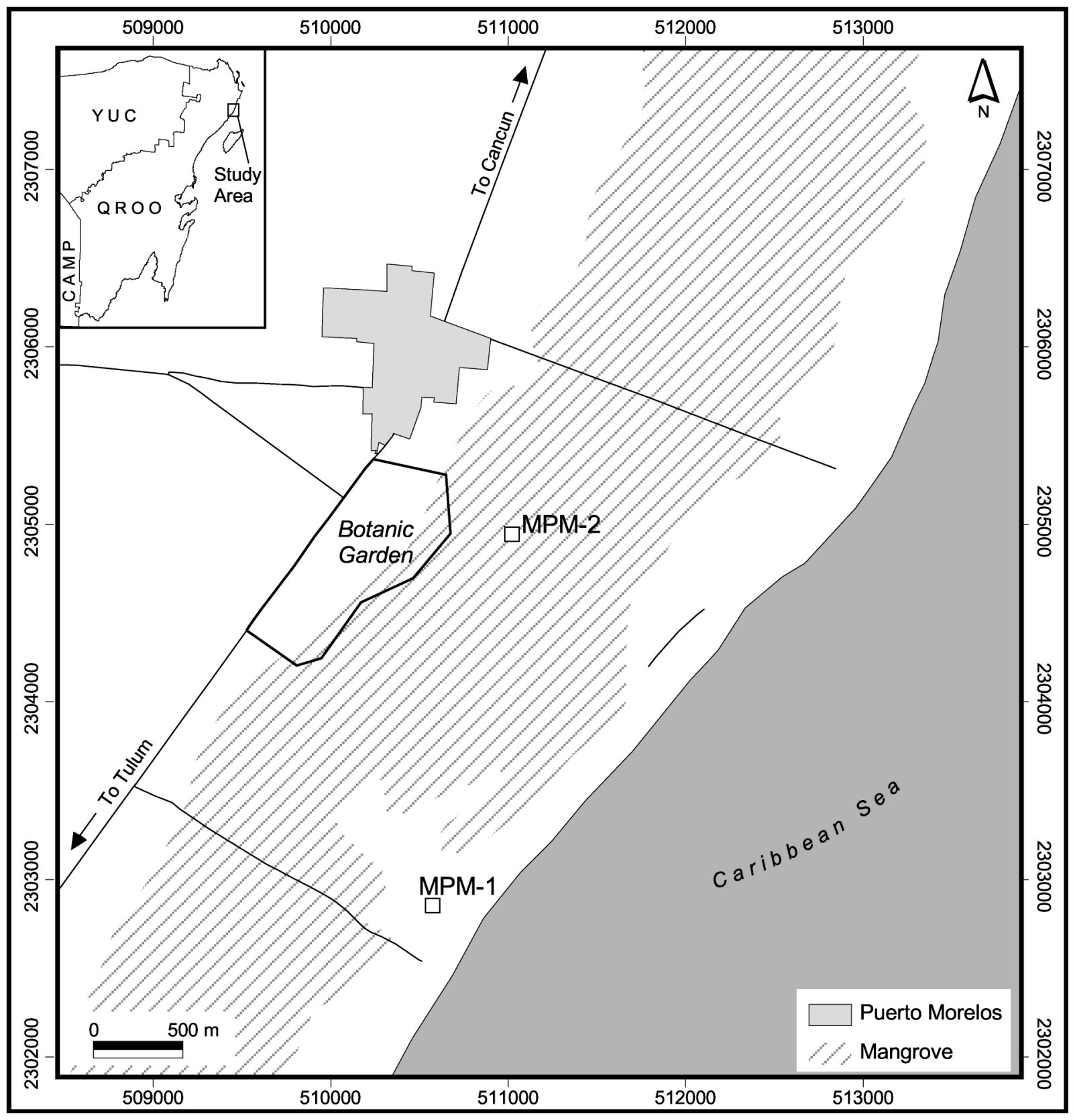

Fig. (1). Study area showing the localities of the cores in the area of Puerto Morelos, Quintana Roo.

more open vegetation. During the period (1200-1000 14C yr $\mathrm{BP}), R$. mangle recover, indicating humid conditions. The last period (1000 14C yr BP till present) suggests a drier period; $C$. erecta and disturbance elements mark the transition to present day conditions [23].

Core MPM-2 has a depth of $105 \mathrm{~cm}$ with $3608-3838 \mathrm{cal}$ yr BP (1889-1659 BC) at the bottom of the core. Sediments are mostly dark peat, rich in organic material; the upper part is sandy, evidence of recent erosion. Two pollen zones were established with CONISS, the cluster analysis shows the association according to similarity (Fig. 2). A possible hiatus was identified in pollen zone II, the sedimentary shift was conspicuous.

\section{Pollen Zone I (3600-3300 cal yr BP)}

Mangrove elements dominate with $>70 \%$ (Rhizophora mangle), while Conocarpus erecta is present with less than $5 \%$. Poaceae and Arecaceae (Palmae) show values of less than $5 \%$, taxa related to more open conditions and sabana vegetation. Percentages of Moraceae, Ficus and Fabaceae between 2 and $10 \%$ indicate forest taxa from nearby medium and low forest. Asteraceae as taxa from secondary vegetation is present with $<2 \%$. Botryococcus is present with $8 \%$ and later shows percentages of $2 \%$. Environmental conditions in this pollen zone suggest higher levels of precipitation compared to present day conditions and allowed the existence of the mangroves, without mayor hydrological fluctuations. 
Table 1. List of Pollen Taxa and their Ecological Groups

\begin{tabular}{|c|c|c|c|c|}
\hline Mangrove/Wetland & Tropical Forest & Disturbance Vegetation & Aquatics & Spores \\
\hline Rhizophora mangle & Malpighiaceae & Poaceae & Botryococcus & Monolete diverse \\
\hline Conocarpus erecta & Moraceae & Myrica & Indet-Egg & Trilete diverse \\
\hline Chenopodiaceae-Amaranthaceae & Ficus & Cecropia peltata & & Fungal spores \\
\hline Arecaceae & Fabaceae & Mimosoidae-Acacia & & \\
\hline Bravaisia tubiflora & Ephorbiaceae & Asteraceae & & \\
\hline \multirow[t]{8}{*}{ Haematoxylum campechianum } & Sapotaceae & Burseraceae & & \\
\hline & Myrtaceae & Croton sp. & & \\
\hline & Rubiaceae & Malvaceae & & \\
\hline & Borreria veticillata & Bignoniaceae & & \\
\hline & Sapium & Convolvulaceae & & \\
\hline & Polygonum acre & Alnus & & \\
\hline & Sapindaceae & Pinus & & \\
\hline & Anacardiaceae & & & \\
\hline & & & & \\
\hline
\end{tabular}

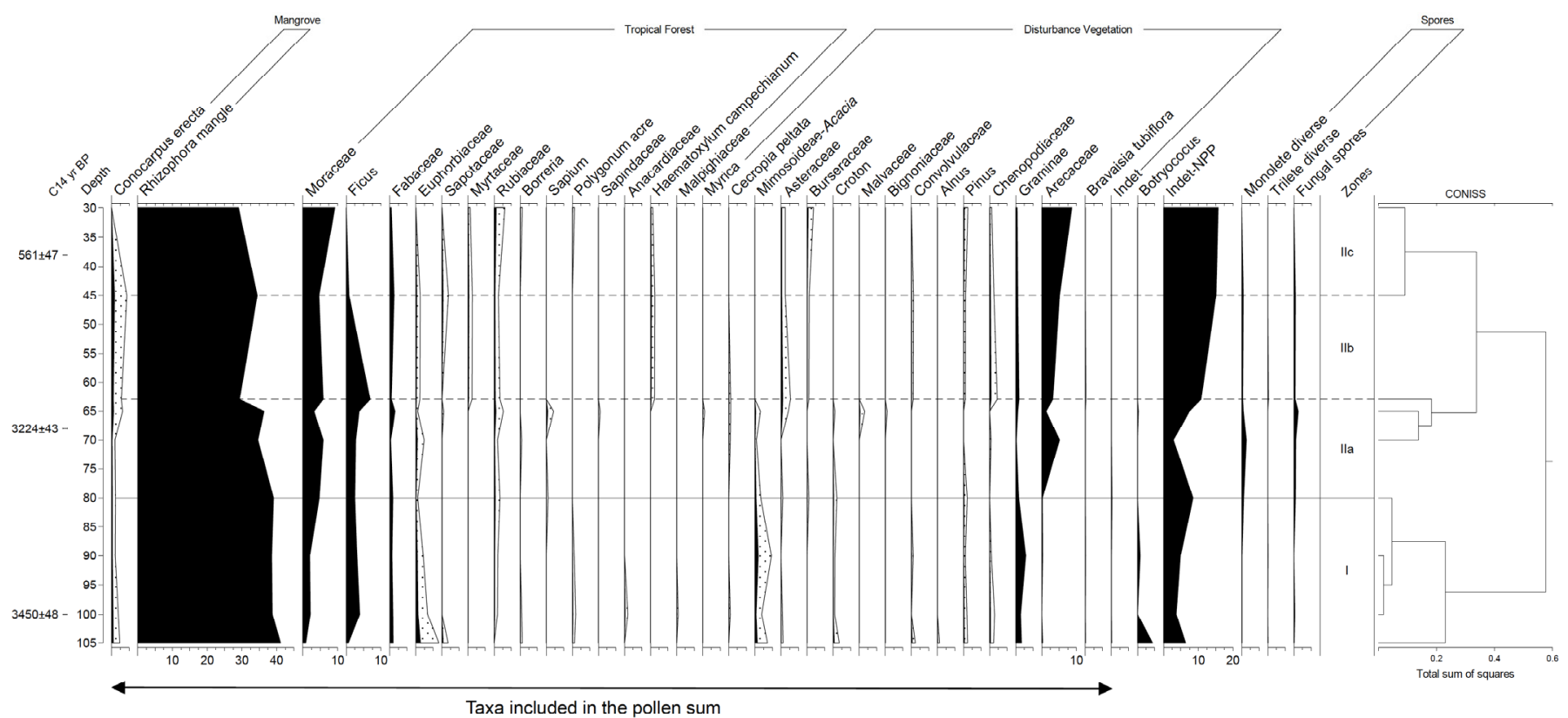

\begin{tabular}{|c|c|c|c|c|}
\hline \multicolumn{5}{|c|}{ Calibration } \\
\hline Lab code & Depth $(\mathrm{cm})$ & $14 C$ age yr $B P$ & $95.4 \%(2 \sigma)$ cal age ranges & $95.4 \%(2 \sigma)$ cal age ranges \\
\hline NSRL-11818 & 38 & $585 \pm 40$ & Cal BP $532-653$ & Cal AD 1297-1418 \\
\hline NSRL-11819 & 63 & $3240 \pm 40$ & Cal BP 3382-3560 & Cal BC 1564-1420 \\
\hline NSRL-11820 & 100 & $3460 \pm 40$ & Cal BP 3221-3446 & Cal BC 1497-1272 \\
\hline
\end{tabular}

Fig. (2). Pollen percentage diagram and radiocarbon data, calibrated with CALIB 5.

\section{Pollen Zone II (3300-100 cal yr BP)}

Three subzones were identified, IIa evidences advance and reduction of mangrove area and coast line shown by variation of mangrove and forest taxa. Rhizophora mangle $(80-65 \%)$ presents some variation, while forest taxa like Moraceae (6-9\%), Ficus (4-7\%) and Fabaceae (1-2\%) show little variation with low percentages. Other forest tax like 
Table 2. Taxa with Significant Values $(\mathbf{P}<\mathbf{0 . 0 5})$, and $\mathbf{r}$ Correlation, the Independent Variable was Depth

\begin{tabular}{|c|c|c|c|c|c|}
\hline MPM-1 & Conocarpus erecta & 9.75 & 0.0081 & 0.43 & -0.54 \\
\hline MPM-1 & Moraceae & 8.79 & 0.0110 & 0.40 & 0.64 \\
\hline MPM-1 & Apocynaceae & 5.86 & 0.0308 & 0.31 & 0.58 \\
\hline MPM-2 & Rhizophora mangle & 14.75 & 0.0064 & 0.68 & 0.82 \\
\hline MPM-2 & Moraceae & 12.04 & 0.0104 & 0.63 & -0.79 \\
\hline MPM-2 & Euphorbiaceae & 11.37 & 0.0119 & 0.62 & 0.79 \\
\hline MPM-2 & Rubiaceae & 6.17 & 0.0420 & 0.47 & -0.68 \\
\hline MPM-2 & Croton & 8.41 & 0.0230 & 0.55 & 0.74 \\
\hline
\end{tabular}

Sapotaceae, Rubiaceae, Gymnopodium floribundum appear with less than $2 \%$, as well as taxa from secondary vegetation like Bignoniaceae, Convolvulaceae, Croton and Burseraceae. A possible sedimentary hiatus could be related to a drastic decrease of taxa. Arecaceae increase and decrease later with percentages between $0.5-10 \%$. Most probable taxa are Acoelorraphe wrightii and Thrinax radiata, which are typical for these localities and correspond to transition zones between mangroves and low forest.

Pollen subzone IIb (Hiatus): Above the possible sedimentary hiatus Arecaceae (2-10\%) and Poaceae $(5 \%)$ slightly increase, Fabaceae have low percentages $(<5 \%)$, Asteraceae remains with less than 5\%. Taxa of the medium statured forest like Moraceae show values between 6 and $11 \%$, while Ficus decreases (9-1\%). Some taxa increase (Rubiaceae and Burseraceae) but with values less than $5 \%$. At the upper part of this pollen zone a clear decrease of taxa associated to humid conditions is observed. Ficus decrease, and can be related to a reduction of available humidity.

Pollen subzone IIc (600-100 cal yr BP): R. mangle slightly decreases $(60 \%)$, which can be related to changes of the coast line. Moraceae and Arecaceae are well represented $(9-20 \%)$ as taxa associated to tropical forest and sabana vegetation. Fabaceae and Ficus show values less than 5\%, as well as Rubiaceae, Borreria, Asteraceae and Burseraceae. Low forest taxa like Haematoxylum campechianum are present with 3\%. Decrease of taxa like Ficus is related to conditions of reduced humidity. Other taxa as Myrtaceae and Sapotaceae give evidence of nearby tropical forest. Percentages of palm taxa indicate that establishment of associations like tasistal (Arecaceae) occurred during the last thousand years.

\section{MPM-1 and MPM-2}

To compare data from cores MPM-1 and MPM-2 Fig. (3) is presented. MPM-1 is a longer sequence but of less age compared with MPM-2 [23], which evidence difference of accretion of the coastal mangrove (MPM-1) and the "inner" mangrove near to tropical forest (MPM-2). The hiatus suggests evidence of strong local hydrological variations, and a possible catastrophic event given the magnitude of change in the sediments. Variation within the vegetation types are conspicuous and express constant change. Mangroves present their highest percentage between 3600 and $3200 \mathrm{cal}$ yr BP. Changes in the tropical forest and of disturbance taxa are minor. After the hiatus the changes seem stronger, which correspond to MPM-1 with a higher resolution of the last 2000 years. MPM-2 shows higher presence of taxa from tropical forest due to its location, while MPM-1 shows higher percentages of disturbance taxa, due to nearby presence of sabana vegetation.

\section{Linear Regression and Correlation}

Table 2 shows linear regression and correlation between taxa/depth of both cores. MPM-22 highlights some taxa as agent of force and direction, in some cases, the relation is negative (Moraceae). In both cores, two taxa present a strong relation with depth (Moraceae and $R$. mangle). Other taxa are indicative of changes of vegetation composition, $C$. erecta tolerates flooding and salinity, Apocynaceae and Solanaceae are taxa of secondary vegetation, associated to zones of transition and influence of sabana vegetation. Taxa of core MPM-22 with significant values correspond to semievergreen forest taxa. Table 3 and Fig. (4) show the results of the correlation, the relationship between taxa was explored to define the association or covariance of each pair. Positive correlation results in MPM between Rhizophora mangle and Moraceae, while for $R$. mangle and $C$. erecta the correlation is negative, this corresponds to the environmental preferences of each species. More relationships for MPM-22 were obtained, and taxa of primary forest have negative correlation with taxa of disturbance (Moraceae \& Euphorbiaceae, Mimosoideae, Acacia, Croton). Disturbance taxa show positive correlation with each other. Taxa such as Arecaceae show higher affinity to taxa of semi-evergreen forest. Comparisons using linear regression and correlation, to identify the association between abundance of each taxa 


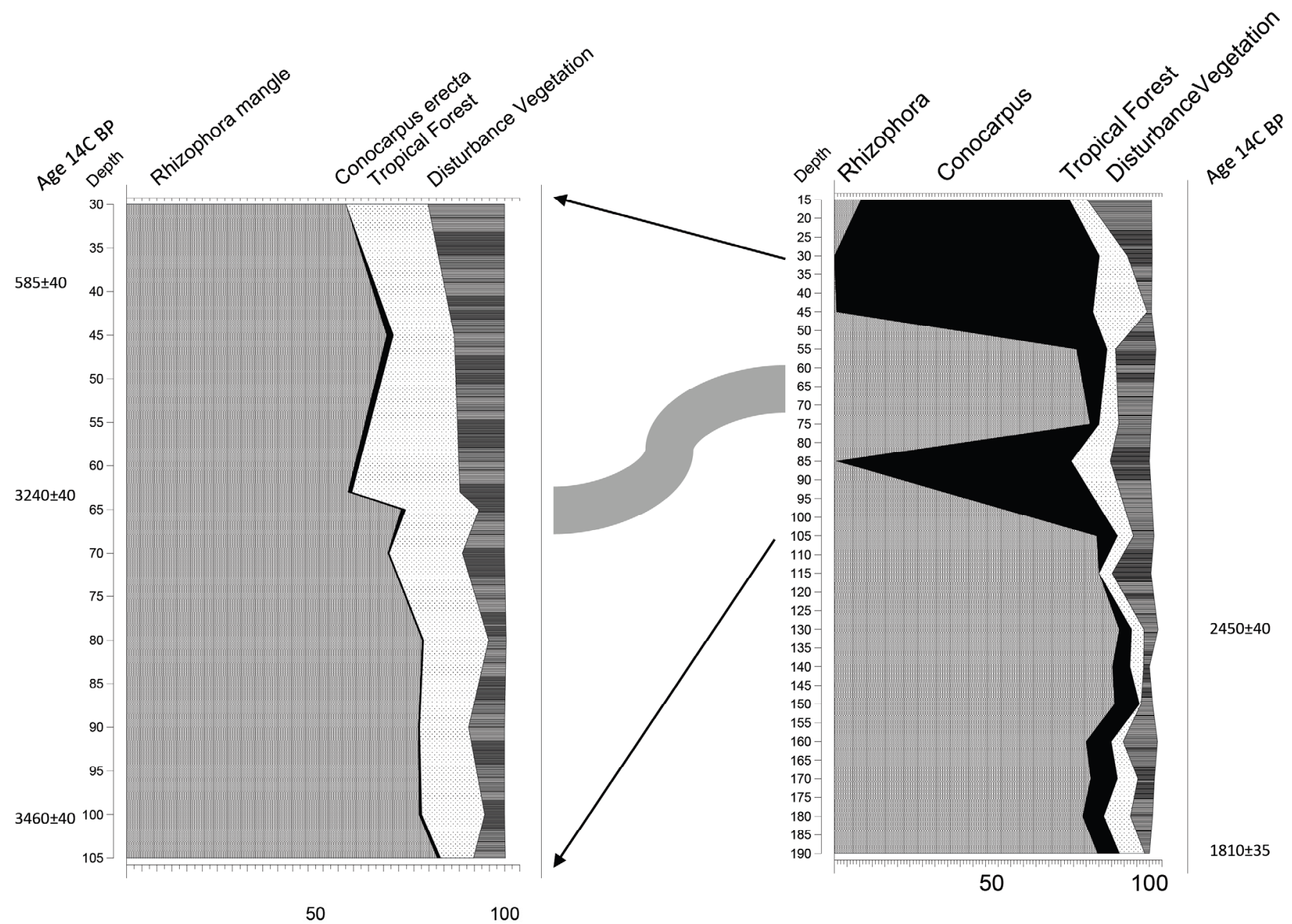

\section{MPM-2}

\section{MPM-1}

Fig. (3). Summary diagrams of cores MPM-1 and MPM-2.

and the affinities between them, allow to establish a calibration of the data.

\section{DISCUSSION}

\section{Paleoecological perspective}

The core MPM-2 represents changes of the mangrove forest during the last 3600 years (Fig. 2). $R$. mangle dominates along to the pollen record, but between 3600 and 3200 cal yr BP is present with percentages between 35 and $43 \%$. However the presence of Poaceae, B. tubuliflora (> 0.5\%), Moraceae, Ficus, Borreria verticillata and Mimosoideae-Acacia indicate some disturbance in the nearby tropical forest. Probably, sea level established similar to present day conditions and benefitted $R$. mangle during this period [25]. C. erecta is present in this pollen zone with $<5 \%$ supporting evidence of changes in sea level. Between 3500 and 3300 cal yr BP the coastline is established.

Arecaceae increase in this pollen zone, indicating development of tasistal vegetation, dominated by the palm species Acoelorraphe wrightii and Thrinax radiata. Moraceae (6-9\%) increased compared to pollen zone I and give evidence of a more mature character of the surrounding forest. A sedimentary hiatus is assumed as a drastic decrease of taxa is observed at $63 \mathrm{~cm}$ depth, and also agrees with changes in core sediments. Following the hiatus, Arecaceae, Moraceae, Fabaceae and Ficus increase. $R$. mangle is present in pollen zone IIb with percentages ranging from 50 to $60 \%$. A vegetation mosaic of mangrove with tasistal vegetation and tropical forest covered the area.

Ficus decreases steadily in pollen zone IIb and indicates a decrease in available humidity. This taxon responds earlier than other forest elements to variations of precipitation. In pollen zone IV, $R$. mangle decreases slightly (60\%), suggesting drier climatic conditions.

Compared to other cores in the wider area, like El Palmar [24] and Puerto Morelos core MPM-1 [23] the dominance of $R$. mangle is conspicuous in the MPM-2 core. In El Palmar core, southern Quintana Roo, C. erecta was evidenced with $20-40 \%$ and even higher percentages in a core from Puerto Morelos (MPM-1). Core MPM-2 however, was cored less than $500 \mathrm{~m}$ distance to the sea with pure $R$. mangle stands, while core MPM-1 was taken 2. $5 \mathrm{~km}$ inwards in a 

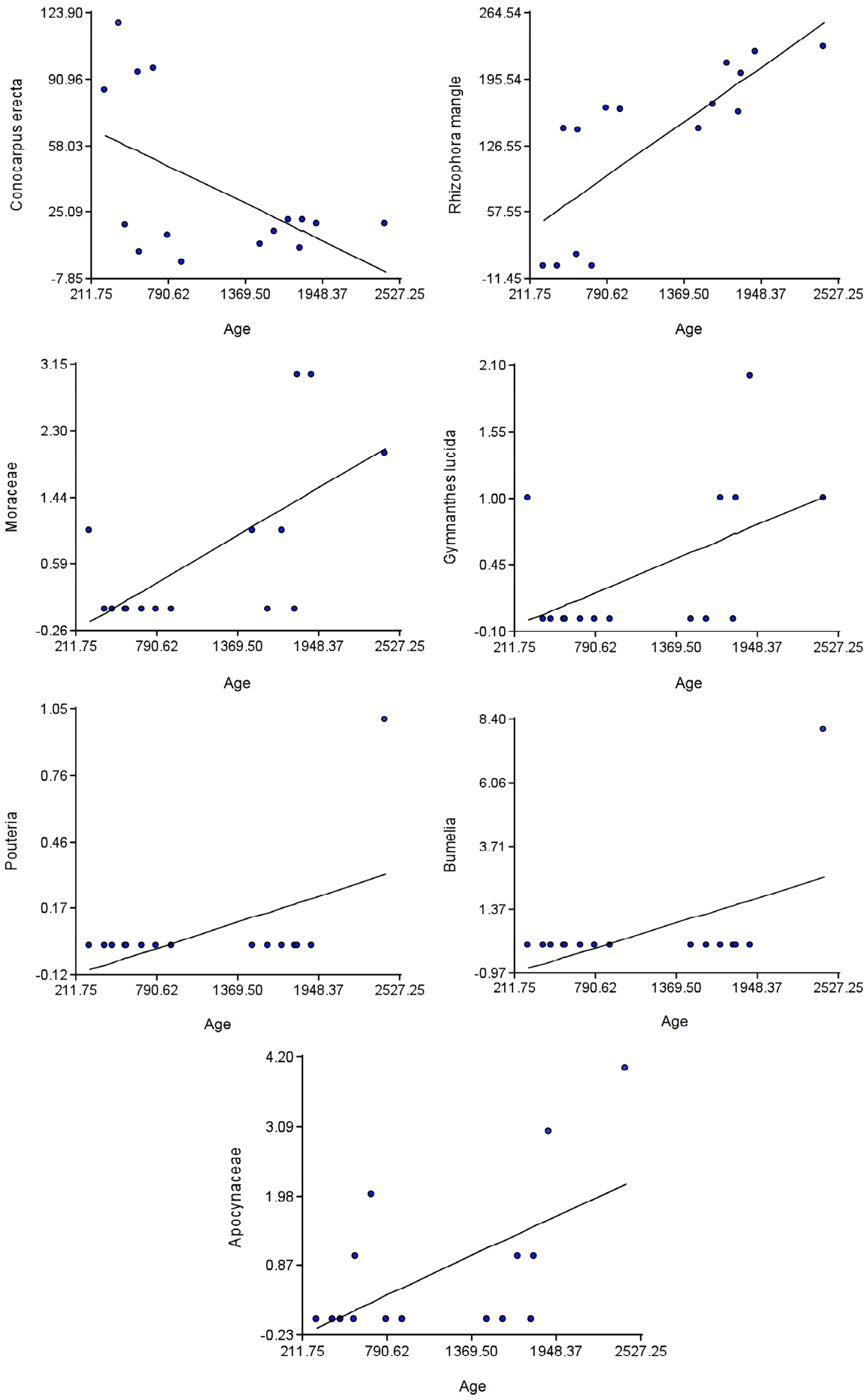

Fig. (4). Correlation between taxa of MPM-1 and MPM-2. 
Rhizophora-Conocarpus vegetation mosaic. Core El Palmar was taken at $23 \mathrm{~km}$ distance from the Caribbean Sea within a mixed forest-mangrove area. Mangrove vegetation from all three types of mangroves reacted to environmental change, but in a time frame of over 4000 years, the overall change is less conspicuous.

Table 3. Spearman Correlation, Taxa with Significant Values were Used (Table 2).

\begin{tabular}{|c|c|c|}
\hline Core & Group & (r) Spearman \\
\hline MPM-1 & Rhizophora mangle \& Conocarpus erecta & -0.3 \\
\hline MPM-1 & Rhizophora mangle \& Moraceae & 0.53 \\
\hline MPM-1 & Moraceae\&Apocynaceae & 0.57 \\
\hline MPM-2 & Rhizophora mangle \& Moraceae & -0.42 \\
\hline MPM-2 & Rhizophora mangle \& Euphorbiaceae & 0.53 \\
\hline MPM-2 & Rhizophora mangle \& Burseraceae & -0.75 \\
\hline MPM-2 & Rhizophora mangle \& Arecaceae & -0.57 \\
\hline MPM-2 & Rhizophora mangle \& Mimosoideae-Acacia & 0.68 \\
\hline MPM-2 & Moraceae \& Euphorbiaceae & -0.61 \\
\hline MPM-2 & Moraceae \& Rubiaceae & 0.6 \\
\hline MPM-2 & Moraceae \& Burseraceae & 0.67 \\
\hline MPM-2 & Moraceae \& Arecaceae & 0.76 \\
\hline MPM-2 & Moraceae \& Mimosoideae-Acacia & -0.83 \\
\hline MPM-2 & Moraceae \& Croton & -0.74 \\
\hline MPM-2 & Euphorbiaceae \& Rubiaceae & -0.91 \\
\hline MPM-2 & Euphorbiaceae \& Bursearaceae & -0.71 \\
\hline MPM-2 & Euphorbiaceae \& Mimosoideae & 0.56 \\
\hline MPM-2 & Euphorbiaceae \& Croton & 0.31 \\
\hline MPM-2 & Rubiaceae \& Burseraceae & 0.53 \\
\hline MPM-2 & Bursearaceae \& Arecaceae & 0.49 \\
\hline MPM-2 & Burseraceae \& Mimosoideae-Acacia & -0.76 \\
\hline MPM-2 & Arecaceae \& Mimosoideae-Acacia & -0.77 \\
\hline MPM-2 & Arecaceae \& Croton & -0.85 \\
\hline MPM-2 & Mimosoideae \& Croton & 0.82 \\
\hline
\end{tabular}

The differences between MPM-1 and MPM-2 respond to changes in the zonation of mangrove forest, differences in microrelief, change in soil type and shape of the coastal margin, which are crucial to the composition of the vegetation. Some changes can point to local factors; however, both cores also reflect regional changes.

\section{Ecological and Conservation Perspective}

Sea level rise is one of the mayor concerns due to effects of climate change. Mangroves would be directly affected [47 and 48]. McKee et al., [6] shows that riverine mangrove systems, e. g. like at El Palmar, southern Quintana Roo, are better protected against sea level rise due to higher rates of mineral accretion. Changes in accretion are observed in MPM-1 and MPM-2, the sedimentation rate is related to the position and local hydrology of the mangroves. The future of mangrove stands in the study area and elsewhere depends on rates of sea level rise. IPCC [48] assumes 3-5 mm/yr considering the effects of global change. However, negative effects of sea level rise are preceded by human impact, like establishment of roads, causing severe hydrological variations in the mangrove area. Eutrophication is another factor causing stress in the mangrove area of Puerto Morelos, although no detailed data are yet available. Submergence happens when the sea level is higher than the sedimentation rate, leading to death of the mangroves. Parkinson et al., [20], based on historical and geological data, modelled the accretion rate in mangroves of Florida related to sea level changes and estimated that stability is maintained with a value of $\sim 3 \mathrm{~mm} / \mathrm{yr}$. Submergence occurred when values reached $\sim 8 \mathrm{~mm} / \mathrm{yr}$. With this increase an additional loss of $1.3 \%$ of global mangroves is estimated and the subsequent loss of coastal environments [49].

Hurricane Wilma hit the mangrove area of Puerto Morelos in 2005 and C. erecta individuals were severely affected compared to individuals of $R$. mangle. C. erecta are generally taller trees than $R$. mangle and show larger $\mathrm{dbh}$ [14] and therefore are more likely damaged with severe hurricanes. However, when hurricane Dean hit the coast of southern Quintana Roo in August 2007, coastal mangrove forest was the most impacted. After 6 months $R$. mangle showed no foliation, however tree mortality was estimated $<$ $2 \%[35]$.

R. mangle stands of the coastal fringe are the most damaged due to the extensive use for tourism activities [50]. Duke et al., [51] estimate an annual loss of 1-2\% of global mangroves. In southern Quintana Roo, Hirales-Cota [9] estimated an annual deforestation rate of 67 ha $(0.95 \%)$, a high value compared to other areas of mangrove deforestation in Mexico. Conservation of mangrove areas in southeastern Mexico can only be guaranteed if destruction of this ecosystem is stopped and local and regional regulations are followed.

\section{CONCLUSIONS}

Rull [27] clarifies the idea of Jackson [52] that ecological time, from weeks to centuries, is insufficient to understand ecological processes as succession and biodiversity patterns, this stresses the need for long term studies. The authors of this paper support the view that short-term changes can be better understood in a long time frame. Main forces of change acting on mangrove forests are climate changes, sea level establishment, natural hazards like hurricanes and human impact. Those factors act on different scales and processes. Changes over the last 4000 years have impacted on the mangrove forests affecting their distribution and composition, but actual fragmentation and contamination of the landscape and climate change could accelerate the disappearance of an entire ecosystem.

\section{CONFLICT OF INTEREST}

Declared none.

\section{ACKNOWLEDGEMENTS}

Conacyt is acknowledged for financial support to the project Reconstrucciones paleoclimáticas y paleoeológicas del holoceno tardío de Quintana Roo and Variabilidad 
clímatica y paleocología de los últimos 1500 años del sureste de México. H. Weissenberger is acknowledged for help with editing.

\section{REFERENCES}

[1] Conabio. Manglares de México. Conabio, México. Available at: http://www.conabio.gob.mx/conocimiento/manglares/doctos/sitios. html. 2008.

[2] López-Portillo J, Ezcurra E. Los manglares de México: una revisión. Maderas y Bosques 2002, 5: 27-51.

[3] Parkinson RW, DeLaune RD, White JR. Holocene sea-level rise and the fate of mangrove forests within the wider Caribbean region. J Coastal Res 1994; 10(4): 1077-86.

[4] Toscano MA, Macintyre IG. Corrected western Atlantic sea-level curve for the last 11000 years based on calibrated 14C dates from Acropora palmata framework and intertidal mangrove peat. Coral Reefs 2003; 22: 257-70.

[5] Macintyre IG, Toscano MA, Lighty RG, Bond GB. Holocene history of the mangrove islands of Twin Cays, Belize, Central America. Atoll Res Bull 2004; 510: 1-16.

[6] McKee KL, Cahoon DR, Feller IC. Caribbean mangroves adjust to rising sea level through biotic controls on change in soil elevation. Global Ecol Biogeogr 2007; 1: 1-12.

[7] Chmura GL, Anisfield SC, Cahoon DR, Lynch JC. Global carbon sequestration in tidal, saline wetline soils. Global Biogeochem Cycles 2003; 17: 1111-20.

[8] Tomlinson PB. The botany of mangroves. Cambridge: Cambridge University Press 1986.

[9] Hirales-Cota M. Cambios de cobertura y servicios ambientales del manglar de franja en la zona costera Mahahual-Xcalak, Quintana Roo. Master's Thesis, El Colegio de la Frontera Sur 2009.

[10] Sánchez SO, Islebe GA. Hurricane Gilbert and structural changes in a tropical forest in south-eastern Mexico. Global Ecol Biogeogr 1999; 8: 29-37.

[11] Sánchez SO, Cabrera-Cano E, Torres-Pech S, Herrera-Escudero P, Serralta-Peraza L, Gómez-Varela C. Vegetación. In: CamarenaLuhrs T., Salazar-Vallejo S, Eds. Estudios ecológicos preliminares de la zona sur de Quintana Roo, CIQRO 1991; pp. 31-48.

[12] Trejo-Torres JC, Olmsted I, Durán R. Manglares de la península de Yucatán. In: Salazar-Vallejo S, Gonzaléz NE, Eds. Biodiversi-dad marina y costera de México, Conabio and CIQRO, Mexico 1993; pp. 660-72.

[13] Tovilla-Hernández C, Orihuela-Belmonte DE, Salas-Roblero, RL. Estructura, composición, regeneración y extracción de madera de los bosques de manglar. In: Espinoza-Avalos J, Islebe GA, Hernández-Arana, H, Eds. El sistema ecológico de la bahía de Chetumal/Corozal: costa occidental del Mar Caribe. El Colegio de la Frontera Sur 2009; pp 45-60.

[14] Carrillo-Bastos A, Elizalde-Rendón EM, Torrescano-Valle N, Flores-Ortiz G. Adaptación ante disturbios naturales, manglar de Puerto Morelos, Quintana Roo, México. Foresta Veracruzana 2008; 10: $31-8$.

[15] De Jesús-Navarrete A, Olivera-Rivera J. Litter production of Rhizophora mangle at Bacalar Chico, southern Quintana Roo, México. Universidad y Ciencia 2002; 18(36): 79-86.

[16] CITES, Apéndices I, II, III. Available at: http://www.cites.org/esp/ app/appendices.pdf, 2007.

[17] Ellison JC, Stoddart DR. Mangrove ecosystem collapse during predicted sea-level rise: holocene analogues and implications. J Coastal Res 1991; 7(1): 151-65.

[18] Parkinson RW. Decelerating Holocene sea-level rise and its influence on southwest Florida coastal evolution: a transgressive/ regressive stratigraphy. J Sediment Petrol 1989; 59: 960-72.

[19] Gabriel JJ, Reinhardt EG, Peros MC, Davidson DE, van Hengstum PJ, Beddows PA. Palaeoenvironmental evolution of Cenote Aktun Ha (Carwash) on the Yucatan Peninsula, Mexico and its response to sea level rise. J Paleolimnol 2009; 42: 199-213.

[20] Parkinson RW, DeLaune RD, WhiteSource JR. Holocene sea-level rise and the fate of Mangrove forests within the wider Caribbean region. J Coastal Res 1994; 4(10): 1077-86.

[21] Milne GA, Long AJ, Bassett SE. Modelling Holocene relative sealevel observations from the Caribbean and South America. Quat Sci Rev 2005; 24: 1183-202.

[22] van Hengstum PJ, Reinhardt EG, Beddows PA, Gabriel JJ. Linkages between Holocene paleoclimate and paleohydrogeology preserved in a Yucatan underwater cave. Quat Sci Rev 2010; 29: 2788-98.

[23] Islebe GA, Sanchez SO. History of late Holocene vegetation at Quintana Roo, Caribbean Coast of Mexico. Plant Ecol 2002; 160 187-92.

[24] Torrescano-Valle N, Islebe GA. Tropical forest and mangrove history from south eastern Mexico: a 5000 yr pollen record and implications for sea level rise. Veg Hist Archaeobot 2006; 15: 191 5.

[25] Monacci NM, Meier-Grünhagen U, Finney BP, Behling H, Wooller MJ. Mangrove ecosystem changes during the Holocene at Spanish lookout Cay, Belize. Palaeogeogr Palaeoclimatol Palaeoecol 2009; 280: 37-46.

[26] Wooller MJ, Behling H, Leon-Guerrero J, Jantz N, Zweigert ME. Late Holocene hydrologic and vegetation changes at turneffe atoll, Belize compared with records from Mainland Central America and Mexico. Palaios 2009; 24(10): 650-6.

[27] Rull V. Ecology and Palaeoecology: two approaches, one objective. The Open Ecol J 2010; 3: 1-5.

[28] Delcourt R, Delcourt PA. Quaternary ecology: a paleoecological perspective. London: Chapman and Hall 1991; pp. 242.

[29] Birks HJB. Contributions of quaternary paleoecology to nature conservation. J Veg Sci 1996; 7: 89-98.

[30] Haila Y. Measuring nature: quantitative data in field biology. In: Clarke AE, Fujimura JH, Eds. The right tools for the job-at work in twentieth century life Sciences. Princeton: University Press 1992; pp 233-53.

[31] Sánchez SO. Análisis estructural de la selva del jardín botánico. In: Sánchez SO, Islebe GA, Eds. El Jardín Botánico Dr. Alfredo Barrera Marín, fundamento y estudios particulares, El Colegio de la Frontera Sur and Conabio 2000; pp. 59-74.

[32] Snedaker SC, Pool DJ. Mangrove forest types and biomass. In: Snedaker SC, Lugo AE, Eds. The role of mangrove ecosystems in the maintenance of environmental quality and a high productivity of desirable fisheries (Contract Report). Gainesville: Center for Aquatic Science, University of Florida 1973; pp. C1-C13.

[33] Lugo AE, Snedaker SC. The ecology of mangroves. Annu Rev Ecol Syst 1974; 5: 39-64.

[34] Pool DJ, Lugo AE, Snedaker SC. Litter production in mangrove forests of southern Florida and Puerto Rico. In: Walsh GE; Snedaker SC, Teas HT, Eds. Proceedings of the international symposium on biology and management of mangroves. Gainesville: Universidad de Florida 1975; 1: 213-37.

[35] Islebe GA, Torrescano-Valle N, Valdez-Hernández M, Tuz-Novelo M, Weissenberger H. Efectos del impacto del huracán Dean en la vegetación del sureste de Quintana Roo, México. Foresta Veracruzana 2010; 11: 1-6.

[36] Ward WC, Weidie AE, Black W. Geology and hydrogeology of the Yucatán and quaternary geology of Northeastern Yucatán Peninsula. New Orleans Geological Society. New Orleans: University of New Orleans 1985; pp. 160.

[37] Olmsted I, López OA, Durán R. Vegetación de Sian Ka'an: reporte preliminar. In: Sian Ka'an: estudios preliminares de una zona en Quintana Roo propuesta como Reserva de la Biósfera. CIQROSEDUE. Cancún, México, 1983.

[38] López Portillo J, Ezcurra E, Maass JM. Los pétenes de Sian Ka'an, Quintana Roo y su relación con gradientes de presión hídrica. Acta Botánica Mexicana 1989; 3: 519-29.

[39] Sánchez SO, Islebe GA, Valdez-Hernández M. Vegetación costera del santuario del Manatí. In: Espinoza-Avalos J, Islebe GA, Hernández-Arana $\mathrm{H}$, Eds. El sistema ecológico de la bahía de Chetumal/Corozal: costa occidental del Mar Caribe, El Colegio de la Frontera Sur 2009; pp. 41-5.

[40] Moore PD, Webb JA, Collinson ME. Pollen analysis. Oxford: Blackwell Science Publications 1991; pp. 230.

[41] Grimm, E. Tilia 1.7.16. Illinois State Museum. Research and Collection Center 2011.

[42] Stuiver M, Reimer PJ. Extended 14C database and revised CALIB radiocarbon calibration program. Radiocarbon 1993; 35: 215-30.

[43] Di Rienzo JA, Casanoves F, Balzarini MG, Gonzalez L, Tablada M, Robledo CW. InfoStat versión 2011. Grupo InfoStat, FCA, Universidad Nacional de Córdoba, Argentina. Available at: http://www.infostat.com.ar

[44] Balzarini MG, Gonzalez L, Tablada M, Casanoves F, Di Rienzo JA, Robledo CW. Infostat Manual del Usuario, Editorial Brujas, Córdoba, Argentina 2008; p. 336. 
[45] Zar JH. Biostatistical analysis. Upper Saddle River, NJ: PrenticeHall 1996; p. 123

[46] Fowler J, Cohen L, Jarvis YP. Practical statistics for field biology. Chichester, UK: John Wiley and Sons 1998; p. 259.

[47] Snedaker SC. Mangroves and climate change in the Florida and Caribbean region: scenarios and hypothesis. Hydrobiologia 1995; 295: 43-9.

[48] IPCC. Climate change: synthesis report. IPCC, Geneva, Switzerland 2007; p. 104
[49] Allen AJ, Ewel KC, Jack J. Patterns of natural and anthropogenic disturbance of the mangroves on the Pacific Islands of Kosrae. Wetlands Ecol Manag 2001; 9: 279-89.

[50] POET-CM. Decreto mediante el cual se reforma el Programa de Ordenamiento Ecológico Territorial de la región Costa Maya, Quintana Roo. Gobierno del Estado de Quintana Roo, SEDUMA, UQROO, 2006.

[51] Duke NC, Meynecke JO, Dittmann S, et al. A World without mangroves? Science 2007; 317: 41-2.

[52] Jackson ST. Integrating ecological dynamics across timescales: realtime, Q-time and deep time. Palaios 2001; 16: 1-2.

Received: November 23, 2011

Revised: December 01, 2011

Accepted: December 25, 2011

(C) Torrescano-Valle and Islebe; Licensee Bentham Open.

This is an open access article licensed under the terms of the Creative Commons Attribution Non-Commercial License (http://creativecommons.org/licenses/by$\mathrm{nc} / 3.0 /$ ) which permits unrestricted, non-commercial use, distribution and reproduction in any medium, provided the work is properly cited. 